\title{
Building information modeling (BIM) systems and their applications in Turkey
}

\author{
S. Maçka Kalfa* \\ Karadeniz Technical University, Department of Architecture, Trabzon, Turkey
}

\begin{abstract}
Building information models (BIM) have been used as common in the architecture, engineering, and construction (AEC) industry in recent years. Each country in the world has tried to adopted BIM systems because of their benefits. Owing to these systems, it could be provided time, labor and money savings and reduced errors in the early design stage of a project. But, usage of BIM systems requires deeply a knowledge, skill, and expertise and unfortunately a number of BIM experts have been not enough in many countries. BIM systems that serve as a bridge among many disciplines such as architecture, civil engineering, mechanical engineering etc. study with software. Selection of confidential and accurate software has a great importance. To provide maximum efficiency from the usage of BIM systems, firstly, it should be known that benefits, risks, challenges of these systems and according to these, a roadmap is drawn. Then, usage aims and the status of BIM adoption in countries should be examined. In this context, in the light of above criteria, it is important that BIM systems that are a new project management approach for Turkey are discussed. In this paper, benefits, risks, and challenges of BIM systems for the architecture, engineering and construction were discussed, the situation in the world and Turkey were examined and applications constructed using BIM systems in Turkey were investigated.
\end{abstract}

\section{Keywords}

Building information modeling; BIM software; Benefits; Risks; Challenges; Adoption

Received: 20 March 2018; Accepted: 23 March 2018

ISSN: 2630-5771 (online) @ 2018 Golden Light Publishing All rights reserved.

\section{Introduction}

Building Information Models (BIM) are described as a system using and storing all of information about architecture, structure, construction, and mechanic of a building along life span. This system is created and visualized a building by means of smart objects. In other words; BIM is the management of information using cloud systems [1]. In the recent years, usage of BIM has been becoming more widespread due to many benefits providing during design, construction and operation periods of new buildings. Building information model allows storing interdisciplinary information within a building visual model and sharing knowledge and communication with project participants. In Fig. 1, information flows between project participants on BIM system are given [2]. BIM is created with object-oriented software. The most popular software are REVIT, ARCHICAD, and BENTLEY. This software runs with smart objects creating building components. These geometric or non-geometric objects have functional, semantic or topologic information. By means of BIM systems, architectural, structural, mechanical, electrical and plumbing models can be

* Email: sibelmacka@ktu.edu.tr 
created as 3D. Then, for time planning-construction simulation and cost analysis, 4D model and 5D model are created [3]. Table 1 shows creating models using BIM software.

By means of three-dimensional smart models, BIM occurs significant changes in the workflow and deadline of the project [3]. There are many usage fields. These are $3 \mathrm{D}$ visualization and real model, simulation-creativity, project-collaboration, construction management and building life cycle supporting. To reduce waste and optimize efficiency through all stages of life cycle of the project, BIM bases on the concept of integrated project delivery that is a new project delivery approach to integrate people, systems, business structures and applications into a collaborative process [4].

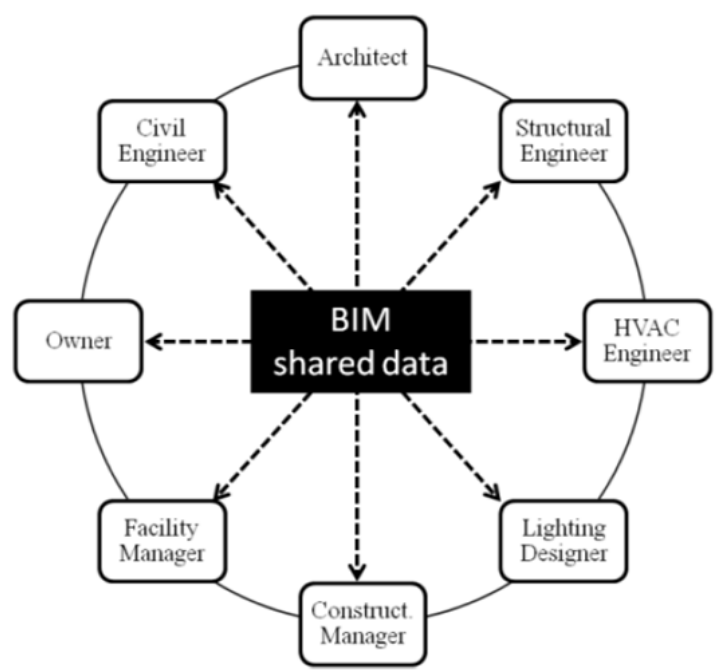

Fig. 1. Information flows between project participants on BIM system [2]

Table 1. Creating models using BIM software

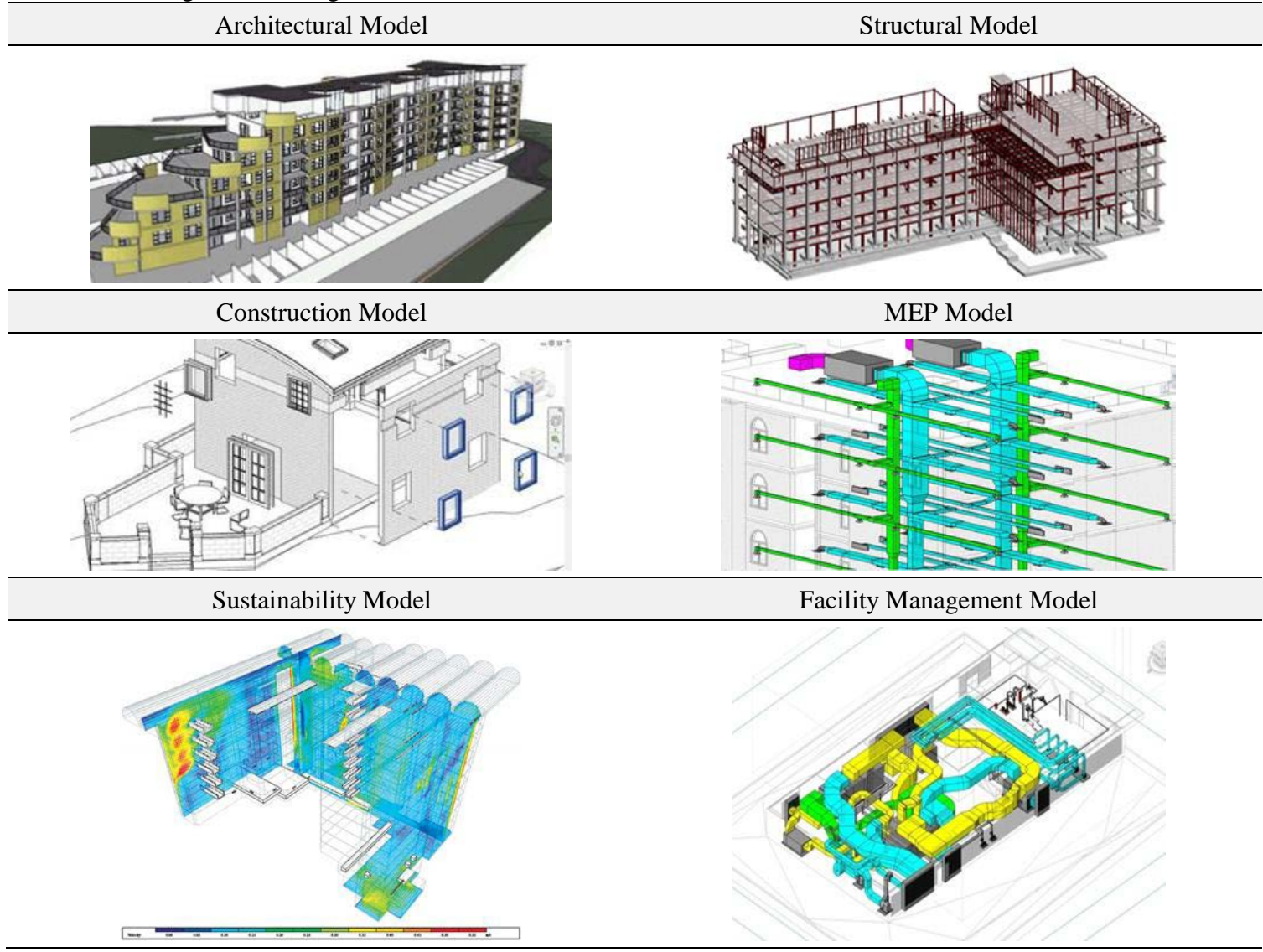


BIM systems provide many benefits according to CAD systems although they have some risks. Most developing countries are adopted BIM systems and they have founded an infrastructure about BIM systems. On the other hand, under developing countries have not been still adopted because of lack of skill and knowledge although they know that practices of BIM systems will be compulsory in near future. For this, this study focus on general information about benefits, risks, and challenges of BIM systems and BIM software. Then, it is discussed usage fields of BIM systems and legal arrangements in the world. Finally, applications of this systems are presented in Turkey.

\section{Benefits, risks, and challenges of BIM systems}

Benefits of BIM systems range from simple improvements consistency, visualization and simulation, coordination and collaboration to greater client satisfaction. Besides these benefits, there are number of risks and challenges. Project participants must take into account these risks and challenges in applications of BIM systems. Benefits, risks, and challenges of building information modeling (BIM) systems are given in Table 2 [1-8].

\section{BIM software}

Nowadays, there have been still several CAD systems without BIM features. However, more companies prefer developing software having BIM features. BIM software are classified six subgroups. These sub-groups are architecture, structure, construction, MEP, sustainability and facility management groups. Each sub-group software services a specific discipline. Sub-groups of BIM software are shown in Fig. 2.

In the result of literature survey, it is seen that ten software developers are the most popular. These developers were founded in different years. Fig. 3 shows founded years of BIM software developers as a timetable.
Table 2. Benefits, risks, and challenges of building information modeling (BIM) systems [1-8].

\begin{tabular}{|c|c|}
\hline Benefits & \\
\hline $\begin{array}{l}\text { - Consistency } \\
\text { - Visualization and } \\
\text { simulation } \\
\text { - Coordination and } \\
\text { collaboration } \\
\text { - Conflict detection and } \\
\text { risk mitigation } \\
\text { - Faster drafting without } \\
\text { loss of cost and quality } \\
\text { - High level of } \\
\text { customization and } \\
\text { flexibility } \\
\text { - Easy maintenance of } \\
\text { building life cycle, }\end{array}$ & $\begin{array}{l}\text { - Optimization of } \\
\text { schedule and cost } \\
\text { - Implementation of } \\
\text { lean construction } \\
\text { - Prefabrication } \\
\text { - Record model } \\
\text { - Construction planning } \\
\text { and monitoring } \\
\text { - Capture reality } \\
\text { - Reduced errors and } \\
\text { omissions } \\
\text { - Reducing overall } \\
\text { project duration }\end{array}$ \\
\hline \multicolumn{2}{|l|}{ Risks } \\
\hline $\begin{array}{l}\text { - Low level of } \\
\text { collaboration } \\
\text { - Low level of team } \\
\text { interest/support } \\
\text { - No BIM planning }\end{array}$ & $\begin{array}{l}\text { - Platform } \\
\text { compatibility, } \\
\text { platform challenges } \\
\text { - Lack of owner BIM } \\
\text { advocacy } \\
\text { - BIM not leveraged for } \\
\text { project meetings }\end{array}$ \\
\hline \multicolumn{2}{|l|}{ Challenges } \\
\hline $\begin{array}{l}\text { - Technical challenges } \\
\text { - Skills and training } \\
\text { challenges }\end{array}$ & $\begin{array}{l}\text { - Technical challenges } \\
\text { - Skills and training } \\
\text { challenges }\end{array}$ \\
\hline
\end{tabular}

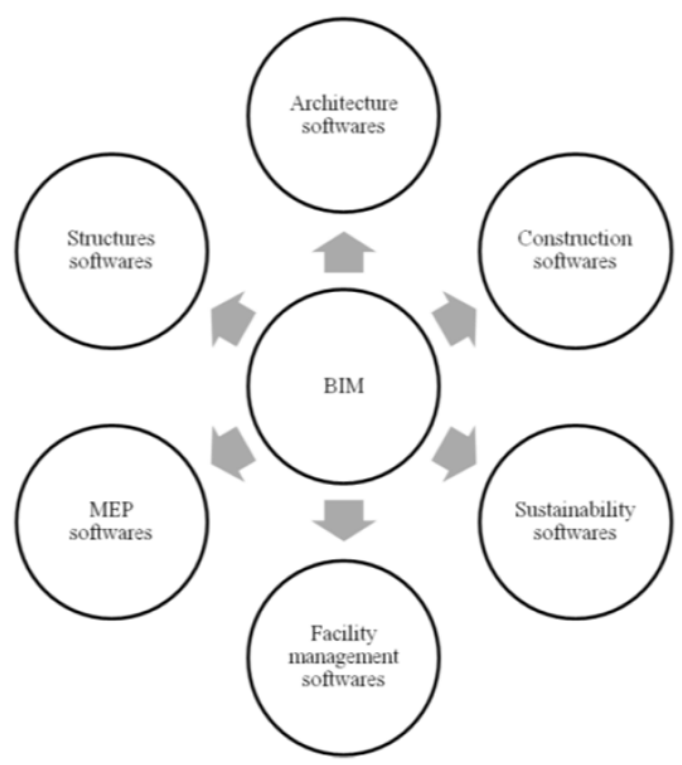

Fig. 2. Sub-group of BIM software 


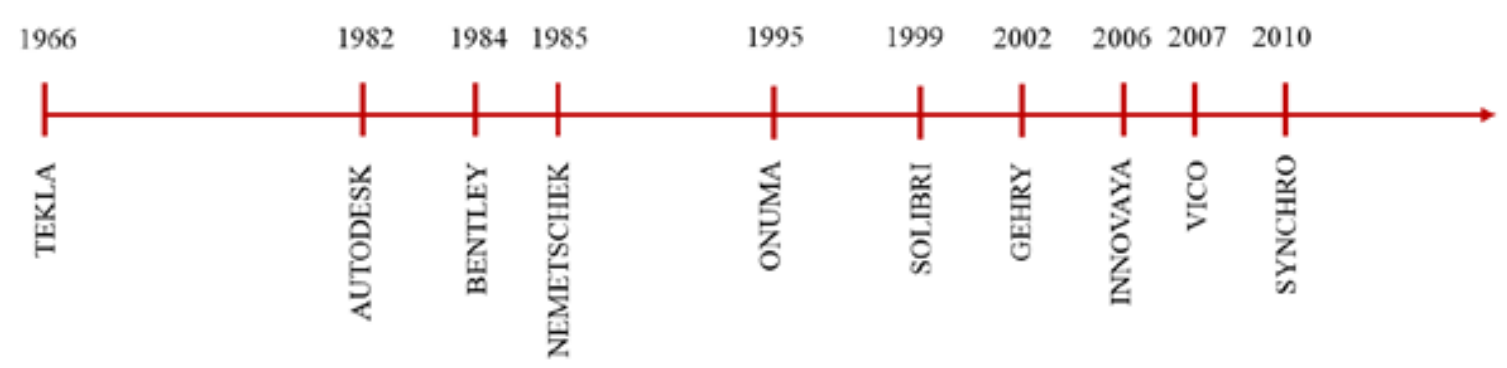

Fig. 3. Founded years of BIM Software Developers [9-20].

Tekla is the first developer of BIM software and was established in 1966, Finland. It focused on structural designs and is developed software such as Tekla Structure, Tekla Structural Designer, Tekla Tedds, Trimble Connect, Tekla Model Sharing, Tekla BIMsight, Teklan Field3D and Tekla Civil to adopt structural solutions to the BIM environment. Nowadays, Tekla manages fabrication, construction and erection stages of all structures such as steel, concrete, and wood [11]. Autodesk that is second important developer was founded in 1982 as an American multinational Corporation. For architecture, engineering and building construction, manufacturing, and media and entertainment, it has been developed many 2D and 3D design software. Its most famous and common usage software in the construction industry is AutoCAD. It is allowed to help users visualize, simulate and analyze the real performance of buildings [12]. Several software developed by Autodesk are Revit, Infraworks, Naviswork Manage, Robot Structural Analysis Professional, Dynoma Studio and 3D Studio Max. Third developer Bentley was established in 1984. It has been studied about solutions in the scale of the building, plant, civil and geospatial vertical markets for architecture, engineering, construction, and operations. Its most popular software is Microstation which is a great rival of AutoCAD. Nowadays its solutions are improved through BIM and the corporation created a new line of packages that are object based parametric [13].

Another important developer is Nemetschek Corporation. It had been studied in the field of architecture, engineering, and construction; entertainment; landscape design; and manufacturing since 1985 and in the recent years, it has tried to integrated BIM technology into its software. The Vectorworks product line is their important solutions. Although it is a great drawing and modeling tool, it is not the best solution for BIM in this corporation. The best solution of this corporation about BIM is Graphisoft. Graphisoft is based in Hungary and they claim that they were the first software in the market that implemented BIM Technologies [14]. Onuma that is the fifth developer was founded in 1972 by Kimon Onuma who is president of the corporation. It started its studies about BIM in 1993. Then, an internet address was created in 1995. Since 1995, a group of architects and computer scientists with Like Minded Industry Leaders have been developing Onuma Planning System (OPS) as an internet server model [15]. After Onuma, Solibri was founded in 1999 to develop and market solutions that improve the quality of BIM and making the design process more efficient. With the goal of optimizing BIM processes, the different Solibri solutions allow the user to analyze the models for integrity, quality, and physical security. It also allows the checking for clash detections and code verification, with a function locating the error on the original model. Its popular software is Solibri Model Checker, Solibri Model Viewer and Solibri IFC Optimizer [16].

Gehry Technologies that is the seventh developer provides technology and services to owners, developers, architects, engineers, general contractors, fabricators, and other building industry professionals. It was founded in 2002 and since then 
it has provided BIM solutions. Trimble Connect and Digital Project are its most popular software [17]. Innovaya developed after Gehry Technologies is one of the new companies that emerged during the BIM boom. The company focuses its solutions on the BIM environment and specifically to the building construction. It also looks at interoperability issues between the Autodesk solutions and other construction management software like Timberline, Primavera or MS Project [18].

In recent years, VICO and SYNCHRO Corporations were founded. VICO was formed through the acquisition of assets from Graphisoft company. It is based on previous solutions from Graphisoft that now work as an independent company. The company offers a complete set of programs that linked the design of the project with the construction phase offering programs that allow to create the model from scratch and simulate construction process inputting cost, creating earn value analysis and "what if" scenarios [19]. Synchro is another company that has emerged during this BIM revolution in the latest years. Synchro focuses its solutions to the project management area and specifically to project schedule, linking the geometry of the project to more than 15 scheduling software allowing the simulation of the project as well as resource management [20].

The most popular software belong to above developers according to groups are given in Table 3. According to studies on BIM, REVIT and Archicad are the most used software in the worldwide [21].

\section{Applications of the building information modeling (BIM) systems in the world}

In global context, BIM systems are used to in many parts of the world in architecture, engineering and construction sectors. However, a limited number of the country has been constituted their own legal arrangements such as standards, regulation, and mandates about BIM systems and presented BIM guidelines. Adoption of BIM systems have been in different levels in countries of the world (Fig. 4).
Table 3. The most popular software belong to above developers [11-21].

\begin{tabular}{|c|c|}
\hline Architecture software & \\
\hline $\begin{array}{l}\text { - Revit Architecture } \\
\text { - ArchiCAD } \\
\text { - Allplan Architecture } \\
\text { - Digital Project } \\
\text { Designer } \\
\text { - Vectorworks } \\
\text { Architect }\end{array}$ & $\begin{array}{l}\text { - } \text { IDEA Architectural } \\
\text { Design (IntelliCAD) } \\
\text { - } \text { Bentley Architecture } \\
\text { - } \text { CADSoft Envisioneer } \\
\text { - } \text { Softtech Spirit } \\
\text { - } \text { RhinoBIM (BETA) }\end{array}$ \\
\hline \multicolumn{2}{|l|}{ Structure software } \\
\hline $\begin{array}{l}\text { - } \text { Revit Structure } \\
\text { - Bentley Structural } \\
\text { Modeler } \\
\text { - } \text { Bentley RAM, } \\
\text { STAAD, and ProSteel } \\
\text { - } \text { Tekla Structures } \\
\text { - CypeCAD }\end{array}$ & $\begin{array}{l}\text { - } \text { Graytec Advance } \\
\text { Design } \\
\text { - Structure Soft Metal } \\
\text { Wood Framer } \\
\text { - Scia } \\
\text { - Strad and Steel } \\
\text { - Robot Structural } \\
\text { Analysis }\end{array}$ \\
\hline \multicolumn{2}{|l|}{ Construction software } \\
\hline $\begin{array}{l}\text { - } \text { Navisworks } \\
\text { - } \text { Solibri Model } \\
\text { Checker } \\
\text { - } \text { Vico Office Suite } \\
\text { - } \text { Vela Field BIM } \\
\text { - } \text { Bentley ConstructSim }\end{array}$ & $\begin{array}{l}\text { - Tekla BIMSight } \\
\text { - Glue (by Horizontal } \\
\text { Systems) } \\
\text { - Synchro Professional } \\
\text { - Innovaya }\end{array}$ \\
\hline \multicolumn{2}{|l|}{ MEP software } \\
\hline $\begin{array}{ll}\text { - } & \text { Revit MEP } \\
\text { - } & \text { Mentley Hevacomp } \\
\text { - } & \text { FineHVAnical Designer } \\
& \text { FineLIFT + } \\
& \text { FineELEC } \\
& \text { +FineSANI }\end{array}$ & $\begin{array}{l}\text { - Digital Project MEP } \\
\text { Systems Routing } \\
\text { - CADMEP (CADduct } \\
\text { / CADmech) }\end{array}$ \\
\hline \multicolumn{2}{|l|}{ Sustainability software } \\
\hline $\begin{array}{l}\text { - Ecotect Analysis } \\
\text { - Green Building } \\
\text { Studio } \\
\text { - } \text { EcoDesigner } \\
\text { - } \text { IES Solutions Virtual } \\
\text { Environment VE-Pro }\end{array}$ & 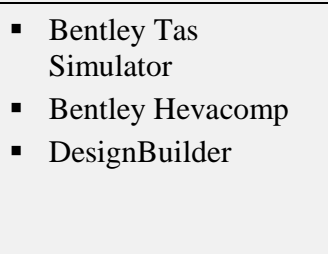 \\
\hline \multicolumn{2}{|l|}{ Facility management } \\
\hline $\begin{array}{l}\text { - Bentley Facilities } \\
\text { - FM: Systems FM: } \\
\text { Interact } \\
\text { - } \text { Vintocon ArchiFM } \\
\text { (For ArchiCAD) }\end{array}$ & $\begin{array}{l}\text { - Onuma System } \\
\text { - EcoDomus }\end{array}$ \\
\hline
\end{tabular}


While USA, Singapore, and Australia have a strong adoption to BIM systems, Japan and China have only strong awareness. It is inevitable that adoption of BIM systems will be started in a very fast way in other countries near future [21-23].

\subsection{United States}

United States has been the strongest leader in the world about BIM systems. US General Service Administration (GSA) provides an implementation of BIM on public projects preparing guidelines and standards. BIM adoption is at about $70 \%$ in US. There's been a lot of entrepreneurial activity and discontinuous efforts to write standards. But we are deep into the adoption curve here. There's no argument about whether it's worth it. BIM is already working. US has many standards, guide, and execution plan about BIM systems. In 2007, US was mandated the use of BIM in all projects. Since 2007, developments, studies have been continued and standards, guidelines have been revised according to requirements [21-23].

\subsection{United Kingdom}

In the UK, Usage of BIM is mandated in all centrally funded public projects in 2016. In 2009, UK was prepared first national BIM standard based on BS1192:2007 standard and US National BIM Standards accepting as an international BIM standard. The UK is now recognized by its peers as one of the leading nations in the exploitation of BIM technology and processes with an internationally respected centrally-led programme. This programme's name is BIS. It has an important role in the development of the standards [21-23].

\subsection{Singapore}

Results of a survey show that $76 \%$ of firms have been used to BIM systems in 2013 in Singapore. Singapore's BIM fund, part of the Construction Productivity and Capability Fund, began in June 2010 and covers costs of training, consultancy, software, and hardware. It is also a world leader in the digitization and automation of the issuing of building permits. The world's first e-submission system was created by BCA Academy in Singapore. Name of this system is CORENET. It enables architects and engineers to check their BIM designed buildings for regulatory compliance through an online gateway. Owing to this system, visualization/presentation were improved $86 \%$, design conflicts were identified and resolved $85 \%$, productivity in CDs was improved $84 \%$, rework downstream was reduced $82 \%$ and errors and omissions in CDs were reduced 81\% [21-23].

\subsection{Scandinavia countries}

Public sector BIM standards or requirements are already in place for Norway, Denmark, Finland, and Sweden, although often at a sub-national level, and led by "intelligent" public sector clients such as Norway's regional health authorities and its Statsbygg government property agency, Finland's Senate Properties, a state-owned enterprise, and Stockholm County Council. In Denmark, a new BIM classification standard was developed by Cuneco. This standard was not only created for Denmark but also for European Union so it is very important for worldwide [21-23].

\subsection{Germany}

Demand for BIM in Germany has been grown rapidly and is driven by foreign investors. They push German architects and engineers to use BIM. In 2013, Construction of Major Projects Reform Commission was founded and BIM-Guide for Germany was created. Then, in 2015, digital building platform was established and it was announced that use of BIM will mandatory for all transportation projects by the end of 2020. In this year, Planen Bauen 4.0 is published as a BIM guideline. It sets out the gradual introduction of BIM practices in four pilot projects until 2017. This will hopefully continue from 2017 to 2020 with further pilot projects and after 2020 result in the full implementation of BIM. Currently, in Germany, there are two tiers of official standardization activities, the first tier is represented by The Association of German Engineers or VDI which is the largest engineering association in Germany with over 15000 members. The organization is 
authorized to produce legally building standards such as the VDI2552 series which is already being drafted. VDI2552 will become the German national BIM standard and will be developed in cooperation with the authorities responsible for BIM standardization developed within the German Institute for Standardization - DIN [21-23].

\subsection{France}

French Ministry of Dwellings and Territories announced a plan in 2014. The aim of this plan is that 500.000 houses are built by using BIM by 2017. BIM systems have been used by major contractors and consultants for many years. MINnD Project was started in 2014 to develop and explore open BIM standards use on infrastructure projects. First BIM standards of France is XP P07-150 BIM standard. It was developed in 2014. In 2015, a PTNB plan was prepared for the digital transition in the building industry and then PTNB bidding process: creation\& operation of a dictionary according to XP P07-150 was constituted in 2016 [21-23].

\subsection{Japan}

In Japan, it was found that BIM implementation has been a high level according to McGraw Hill's report. BIM systems have been mostly used for supply chain management, model-driven robotics and post construction activities in Japan. In 2010, Ministry of Land, Infrastructure, and Transport (MLIT) announced "Start of BIM pilot project in a government building and repairs”. Then, Japan Institute of Architects (JIA) released the BIM guidelines and MLIT Government Buildings Department began to study for the development of BIM modeling rules in 2012. Development of BIM Guidelines has been delayed from pioneering countries [21-23].

\subsection{Australia}

In Australia, first BIM guideline was created by CRC and Australian Institute of Architects in 2009. Then, Australian and New Zealand Revit Standard and NATSPEC BIM Portal were constituted, respectively in 2011. Recently, Australia has strong adaption BIM systems [21-23].

\subsection{China}

China has made BIM part of its most recent fiveyear economic plan. But adoption of BIM is not necessarily as simple as decreasing it. There are some structural differences to the Chinese market: it's controlled top-down and there's a lot of entrepreneurial activity. The two forces are not aligned. China has a national BIM standard. In 2014, Unified Standard for BIM Application had been completed [21-2 23].

\subsection{Brazil}

Brazil is starting to get a grip on BIM and it is moving very fast. Brazil has a reputation as an academic BIM center - its universities are third behind the US and Sweden on publishing BIMfocused academic papers. In terms of practical applications, Brazil's National Department of Transport Infrastructure is embracing BIM in the hope of making 30\% cost savings [21-23].

\section{Applications of the building information modeling (BIM) systems in Turkey}

Usage of BIM systems has been increasing in Turkey in recent years. Because of reasons such as lack of legal arrangement, knowledge, skill, and experience etc., this increment ratio is low level. We can distinguish three categories usage of BIM systems. These categories are academic usages, office usages, and certificate foundation usage.

\subsection{Academic applications}

There are several experts study on BIM systems in universities in Turkey. They attend courses about this topic in different universities. Table 4 shows courses about BIM systems in universities of Turkey. When we investigate Table 4, it is seen that courses are attended the most important student cities of Turkey. The reason of this is generally transferred of information from these cities to other 


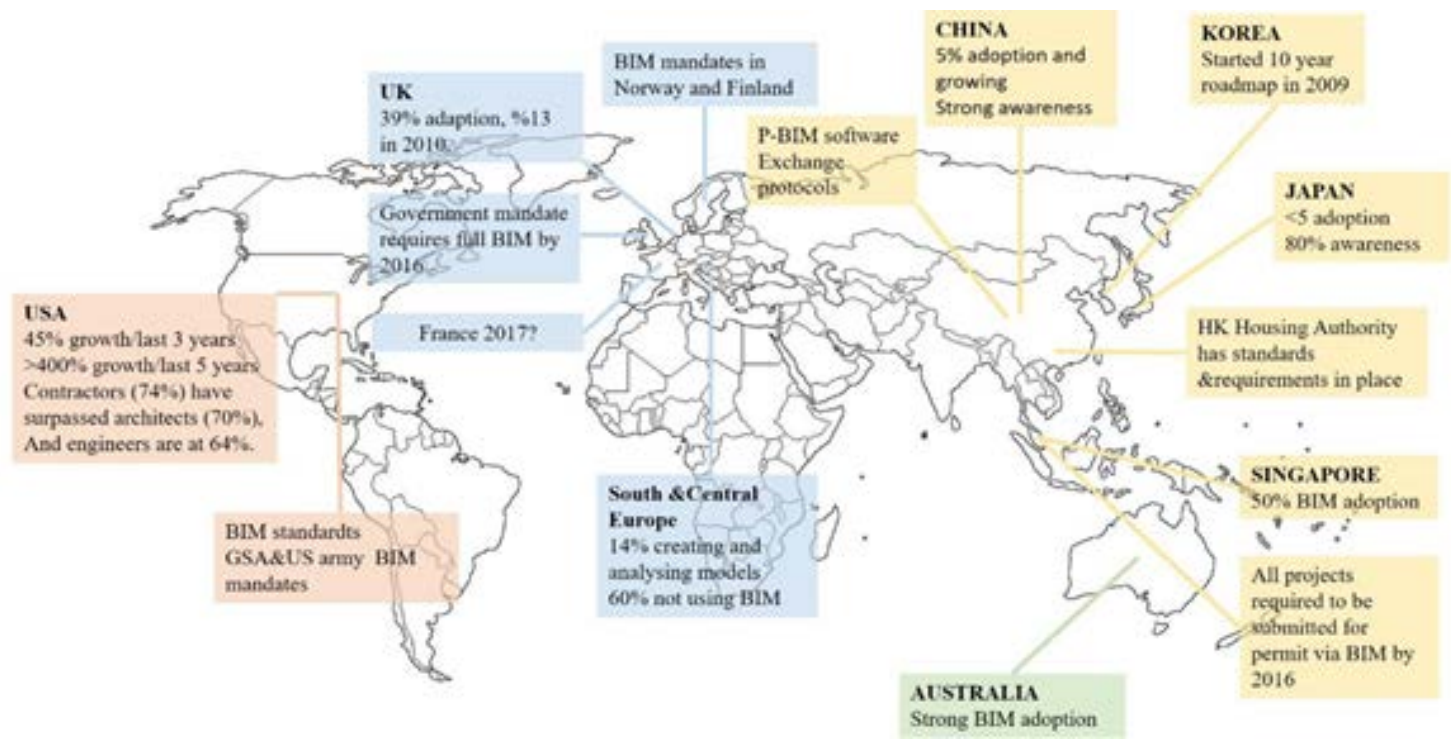

Fig 4. Adoption of BIM systems in different countries of the world [21-23]

Table 4. Courses about BIM systems in universities of Turkey

\begin{tabular}{llll}
\hline University & Department & Program & City \\
\hline Istanbul Culture University & Architecture & Bachelor & Istanbul \\
Beykent University & Design and construction management & Un.graduate & Istanbul \\
Istanbul Technical University & Construction management & Un.graduate & Istanbul \\
Istanbul Technical University & Interdis. Construction Project Management & Un.graduate & Istanbul \\
Izmır Economy University & Architecture & Bachelor & Izmir \\
Karadeniz Technical University & Architecture & Bachelor & Trabzon \\
Karadeniz Technical University & Civil Engineering & Un.graduate & Trabzon \\
Mimar Sinan University & Architecture & Bachelor & Istanbul \\
Yıldı Technical University & Architecture & Un.graduate & Istanbul \\
Yıldız Technical University & Architecture & Bachelor & Istanbul \\
İzmir Institute of Technology & Architecture & Un.graduate & İzmir \\
Middle East Technical University & Building Science & Bachelor & Ankara \\
\hline
\end{tabular}

cities. In future years, it hopes that academic usages have becoming increased.

\subsection{Office applications}

Applications of BIM systems have increased in architecture, engineering and construction sectors in last decades. A good many offices are realized to their projects by means of BIM systems (Fig. 5).

As a tool of BIM systems, they use software such as REVIT and ARCHICAD. According to researchers, these software are the most popular software using in Turkey. Usage aims of BIM systems by offices in Turkey are listed below according to staffs of offices.

- 3D visualization, real model

- Resource and labor efficiency

- Time and cost efficiency

- Interdisciplinary collaboration, flow information

- Clash detection

- Energy analysis, performance evaluation, LEED certificate

- Smart objects

- Fast project, easy revision 
DOME\&PARTNERS

GAD Architecture
DEMIRCE Architecture

ANEL Group
TAV Construction

ERA Architecture

TRES Architecture

ARKAD Architecture

TEKFEN Engineering

VEN Architecture

EPIQ Architecture
DBC Architecture

DERE Construction

TOCAArchitecture

\section{DEKO Engineering}

PROBI Engineering

TABANLIOGLI Architecture
GOKHAN AKSOY Architecture

RONESANS HOLDING

DINAMIK Project

ROTI Design

DOLMEN Building

Fig. 5. Offices using BIM systems in Turkey

In last decades, more offices using BIM systems are preferred personals having skill and expertise about BIM systems and using BIM software such as REVIT and ARCHICAD. Many offices provide training opportunities to their personal about BIM systems by means of education and consultancy offices such as PROTA, CADBIM, INFOTRON or support participation certificate programs. In Table 5, three office using BIM systems were investigated according to different categories.

\subsection{Certificate program applications}

Correct usage of BIM systems and its tools depend on the level of skill and expertise about this topic. Skill and expertise are achieved by means of training. Training must be given by experts of topics. For this purpose, several certification programs have been arranged in Turkey. These programs are listed below.

ITUSEM (Istanbul Technical University) certificate program

- First module- Training Program of Building Information Modelling (BIM) Processes (21 hours in total)

- Second module- Training Program of Building Information Modelling (BIM) Applications (21 hours in total)

- Third module- Certificate Program of Building Information Modelling (BIM) Expert (21 hours in total)

INFOTRON BIM Consultancy and Training Services
- BIM Beginner Training (40 hours in total)

- BIM Advanced Training (24 hours in total)

\section{Conclusions}

Building information modeling (BIM) requires an interdisciplinary knowledge which includes the integration, storage, and exchange of data from several disciplines. Because of this, it has been recognized as one of the most appropriate platforms for the Architecture, Engineering and Construction industry, which is considered to be multiorganizational and multi-disciplinary. Nowadays, developed and underdeveloping countries have been try to adopted BIM. While some countries such as USA, United Kingdom, Singapore, Scandinavia Countries, Germany, France, Japan, Australia, Hong Kong, China, and Brazil were provided highly adoption levels, other countries did not provide. It is clear that adoption of BIM has been increasing day by day all of the world because building information modeling has become essential for efficient project management, better coordination, communication, visualization.

It is very important to know what software is working to use BIM systems properly and to select the software to be used correctly. There are many BIM software on the market. However, it requires experience and deep knowledge in the use of these software. It is necessary to analyze the benefits, risks, and challenges of this system in order to obtain 
Table 5. BIM system applications of investigated offices in Turkey [24-26]

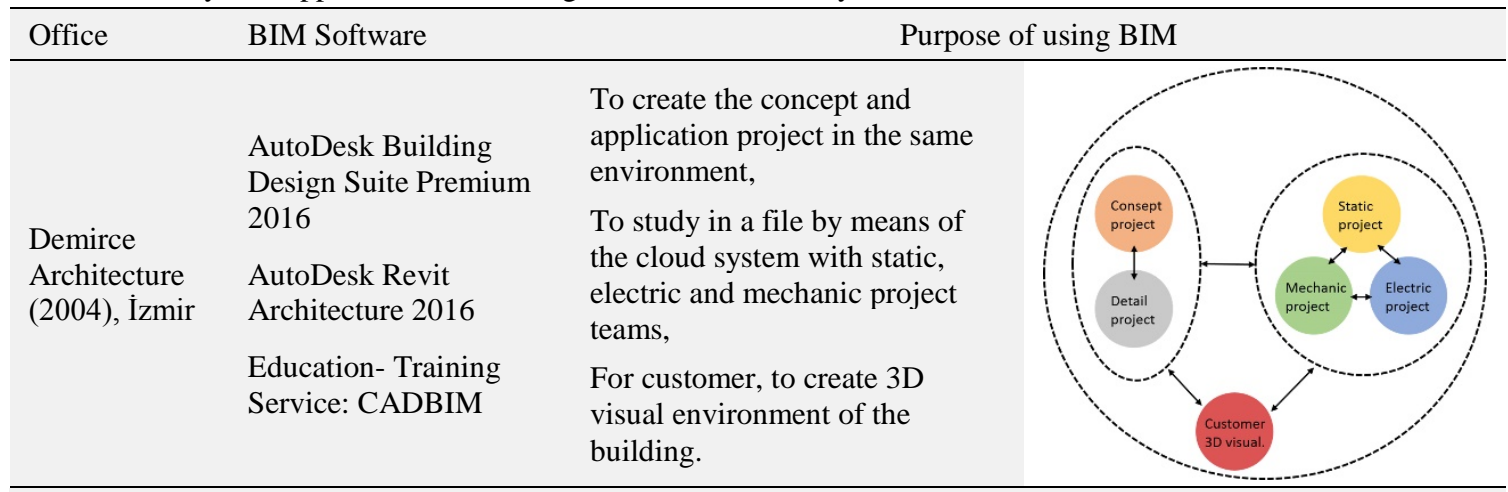

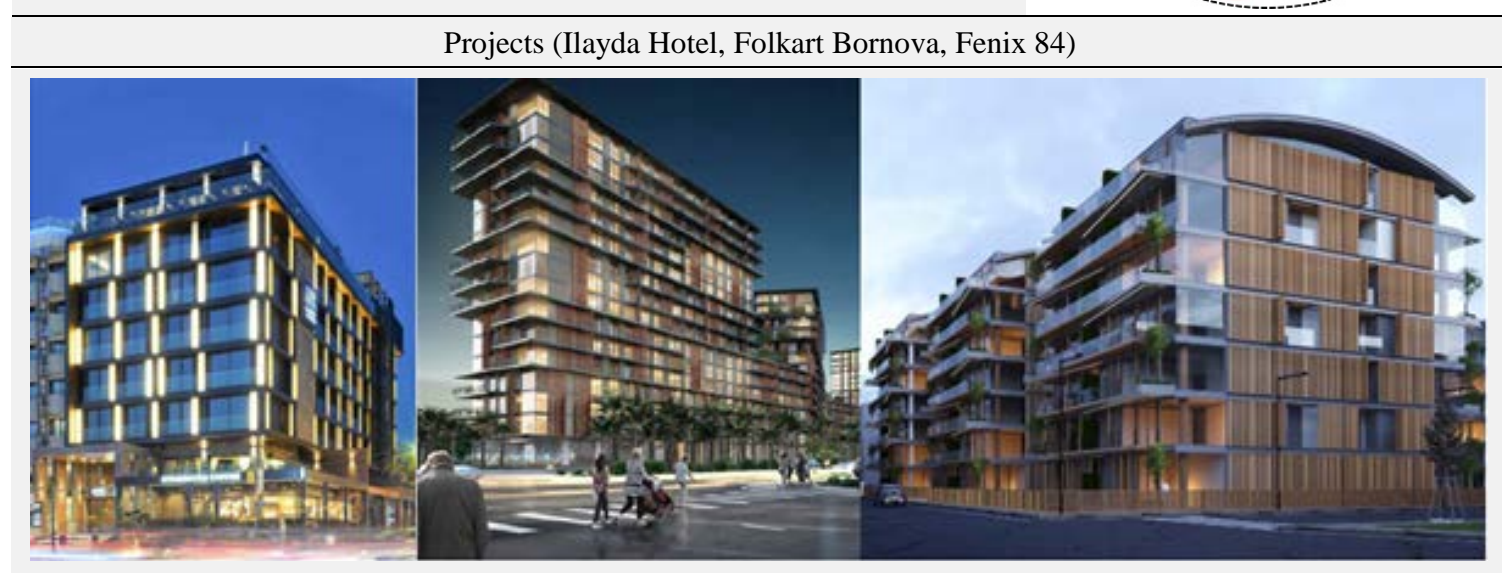

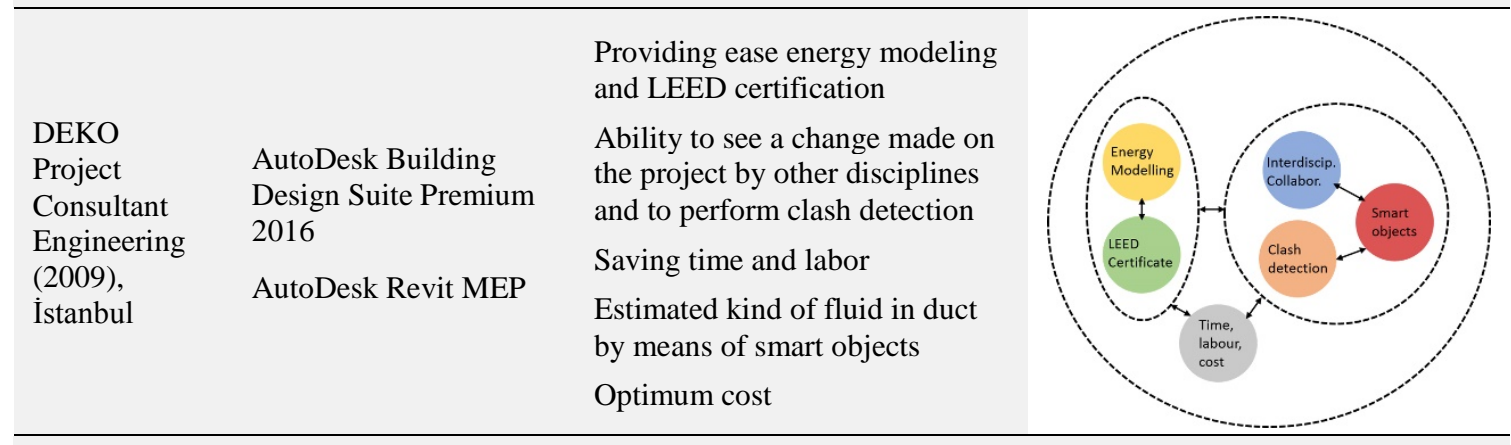

Projects (MP Mechanic room, Mechanic project)

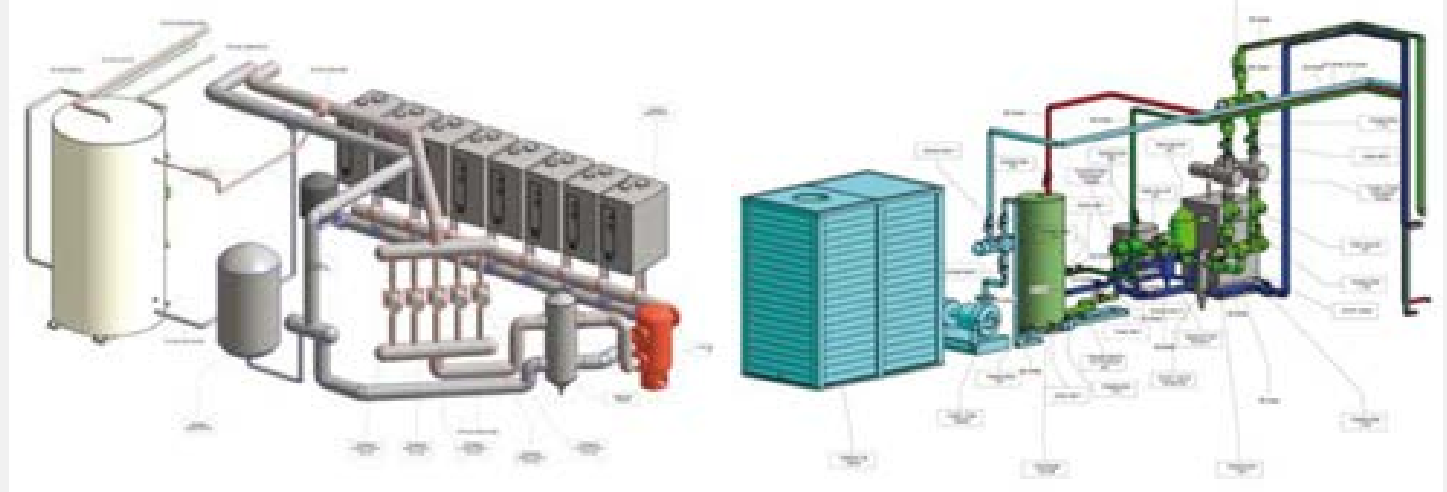


Table 5. Cont'd

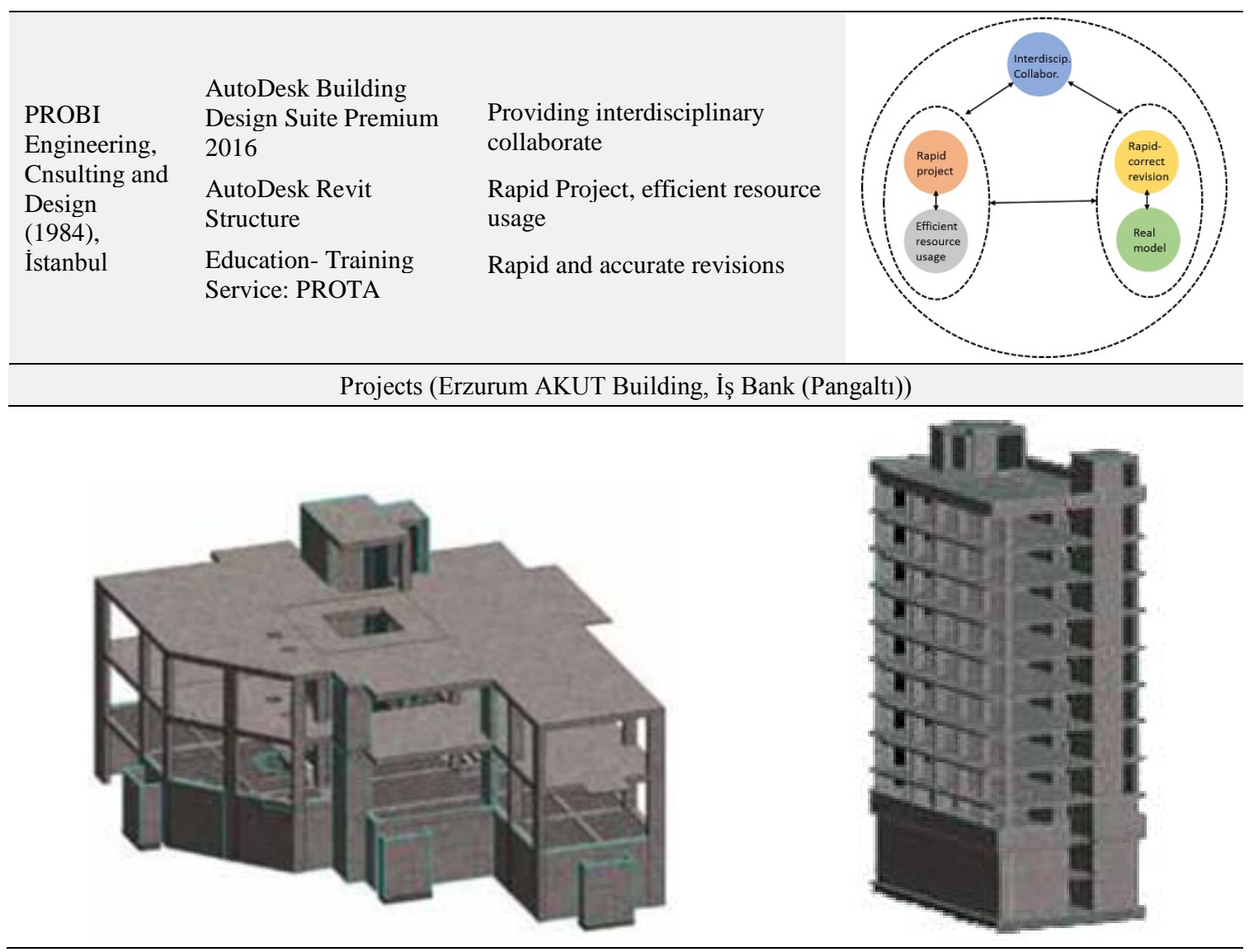

maximum benefit from the use of BIM. The use of BIM systems, which are frequently used in many developed countries in the world, has increased in Turkey in recent years. However, lack of expertise in this regard, lack of knowledge and experience limit the use of BIM. In Turkey, several universities are taught on BIM, certificate programs and BIM specialists are being worked on, and projects are used in projects in major cities. However, there is no legal regulation regarding the use of BIM. In the near future, adoption of Turkey to the BIM system should be ensured and legislation should be enacted in this respect.

\section{References}

[1] Kensek K., Noble D. Building Information Modeling: BIM in Current and Future Practice, London, United Kingdom: Wiley, 2014.
[2] Eastman C., Teicholz P., Sacks R., Liston K., BIM Handbook: A Guide To Building Information Modelling For Owners, Managers, Designers, Engineers and Contractors, New Jersey, USA: Wiley\&Sons, 2011.

[3] Hardin B., McCool D. BIM and Construction Management: Proven Tools, Methods and Workflows, Indiana, USA: Wiley\&Sons, 2015.

[4] Glick S., Guggemos A. IPD and BIM: Benefits and opportunities for regulatory agencies. In:45th Associated Schools of Construction National Conference; Gainesville, FL, 2009.

[5] Building Information Modelling, Brochure, InfoComm International,

[6] https://www.infocomm.org/cps/rde/xbcr/infocom m/Brochure_BIM.pdf. 10.10.2017.

[7] Azhar S. Building Information Modelling (BIM): trends, benefits, risks and challenges for the AEC industry. Leadership and Management in Engineering 11(3) (2011) 241-252. 
[8] Bryde D., Broquetas M., Marc J. The project benefits of Building Information Modelling (BIM). International Journal of Project Management 31 (2013) 971-980.

[9] Rokooei S. Building Information Modeling in project management: necessities, challenges and outcomes. Procedia - Social and Behavioral Sciences 210 (2015) 87-95. 